\title{
Socio-Psychological Effects of Political Violence and War on Gender in Nigeria
}

\author{
Eke Chijioke Chinwokwu \\ Sylvia Kaka Arop \\ Department of Sociology, Federal University Lafia, Lafia - Nigeria
}

\section{Doi:10.5901/mjss.2014.v5n26p44}

\section{Abstract}

This paper examines the effect of political violence and war on gender in Nigeria with particular focus on the sociopsychological dimensions. In the last decade, Nigeria has witnessed various potholes of political violence and some kind of religious or political war that has greatly influenced the sensibility of every sane individual across the globe. The effect of this, especially on the female gender, children and the aged had been grievous and devastating. Recently, the abduction of over 200 school girls from a government college in Chibok, Borno state, Nigeria by a religious fundamentalists group gave terrorism and other criminal violence a new dimension and trend in Nigeria. It also portrays a great danger not only to Nigerian child but to all humanity residing in Nigeria. Unfortunately, instead of the situation to mitigate, it is rather worsening and the sociopsychological effect on genders can only but imagined - from loss of life, displacement of persons, mental stress amongst others. The paper calls for a holistic approach including building a synergy amongst security agencies, enhance security awareness within the society, partnering with foreign forces and using concerted dialogue to end the menace amongst others as way forward in tackling the menace of political violence and war in Nigeria.

Keywords: Political violence, War, Conflict, Socio-psychological, Gender, Nigeria.

\section{Introduction}

The history of Nigeria, immediately after attaining our republican status had been greeted with various kinds of political violence and war. The implication is that men, women and children had been on the receiving end of all these problems. We note that Nigeria remains a multi-ethnic nation state which has between 350-500 linguistics groups and may be populated by fairly half Christians and Muslims (Salawu, 2010; Paden, 2008; Tiffen, 1968; Hansford, Bendor-Samuel \& Stanford, 1976). In fact, political violence and war affect all sections of the country and it is not particular to any ethnic group.

According to the United Nations report on the state of the world population in 2000, gender based violence is said to constitute a life - long that millions of women and girls across the globe (United Nations, 2000b). Amnesty International (2004) notes that human rights situations across the region of Africa is characterized by widespread armed conflict (war) and political repression (violence) and that in all, women are at the risk end. However, men are at the forefront of these wars and political violence. Men suffer death and permanent injuries subjecting women and children to untold hardships ranging from economic stress to socio-psychological imbalance.

The threat and the experience of war and political violence are generally regarded as very distressful and traumatic for women, children and the aged of all sexes. Research shows that 60-80\% people exposed to war and political violence directly or indirectly suffer symptoms of post traumatic stress. Research findings also indicate that mere living in a violent prone area where the media is filled with images and reports of horrible violence destruction as we are witnessing in Nigeria presently can result in people experiencing symptoms of post traumatic stress (Stavrou, 1993). More importantly, children are more at risk than adults during political violence and war. Researches findings indicate that $80 \%$ of children had symptoms of post traumatic stress disorder one to two years later (Stavrou, 1993).

Studies have found that political violence and war have negative effects on the children, and these include heightened aggression and violence, revenge seeking, anxiety, depression, withdrawal, sleep disorder, fear and panic, poor school performance and involvement in criminal violence (Sagi-Swartz, Seginer \& Adeen, 2008; Quota, Runmaki \& El-Sarraj, 2008). More so, children are found to be victimized by or witness to different kinds of political violence and war especially in the community where the family lives (Richters \& Martinez, 1993b). In most African countries like Liberia, Congo, Sierra Leone, Algeria, Angola, Ethiopia, Senegal, Sudan, Uganda etc, children are seen to have been recruited into militant camps and actually carry gun to kill their fellow citizens. About a third of world's children soldiers are found in 
Africa. It is important to understand that child soldering which is rampant in Africa is a result of war, insurgency, political violence, and others. Parents have the hard task of monitoring the behaviour and activities of children to avoid the risk of anti-social behaviour during moments of political violence and war ( Mazefsky\& Farrel, 2005; Okolie, 2005). The risks in which children, women and the aged are exposed to and the effects can be long lasting in the society.

The Nigerian experience since after the civil war and the current insurgency in the country coupled with political violence in the last two decades have greatly affected the citizens especially children, women and the aged. It has produced many widows, widowers, orphans, and increased mental health of citizens. For instance, Human Rights Watch (2007) estimates that a minimum of 300 Nigerians were killed in political violence in the 2007 elections which was higher than those reported in 2003 elections. However, the European Union Election Observation Mission (2007) reports that about 200 people died in political violence within two weeks between April 14 and April 21, 2007 election. The aftermath of April 2011 general election in Nigeria which claimed over 800 lives and over 65,000 displaced persons especially in Northern Nigeria (Human Right Watch, 2011) is still very fresh in our memory. We are still being ravaged by the scourge of insurgency across the country, especially the North East, Nigeria has become a battle ground which has even attracted foreign allies to rescue the citizens from the raging storms of violence in that zone.

It must be noted that political violence and war are orchestrated by the attitudes and utterances of our political elites who believes that election is won by violence and use of political thugs. Accordingly, Obasanjo (2002:50) asserts "we fight and sometimes shed blood to achieve and attain political power because for us in Nigeria, the political kingdom has for too long been the gateway to economic kingdom". Thus "when they said political competition for control of the state and its political power is now a bloody warfare as the state holds the key to wealth" (Omoweh \& Okanya (2005:303) cone will understand why there is too much tension and insecurity in the country as 2015 general election approaches. Hence, Abbass (2008) described election in Nigeria as warfare. Cervellati and Sunde (2011) argue that "democratization process may trigger political violence because the scenario under which democratization takes place especially during democratic transitions provides convenient platforms for violent conflicts, especially among groups within a polity" (cited in Segun, 2013,328). It is not also out of place to aver that the myriad of conflicts across the country is engineered by the political class who only stands to benefit from the violence.

\section{Research Methodology}

This paper is a qualitative study which is based on secondary data. The study was carried out through the meta-analysis of reports on political violence and war in Nigeria and across the globe. Extant and relevant literature on political violence and armed conflict (war) were reviewed, which led to insight exciting study.

\section{Conceptualization of Terms}

Although political violence has become a global phenomenon, getting scholars to accept a common definition for the phenomenon has been awfully difficult. Thus, attempts to define the concept have aroused argument among members of the intellectual community. Dumouchel (2014) contends that political violence is a violence that is committed in the context of a political conflict, or that which can be related, either through its cause or motive, to political issues. According to Dumouchel (2014:119), political violence is "public and rather than private violence" However, Cohan (2006:925) defines political violence as "a legitimate, justifiable means to wage a long term ideological battle against a hostile government". Cohan sees political violence from the ideological point of view and presupposes that it is always carried out against a constituted hostile government. It ignored political violence that is committed against citizens by government. Political violence has been classified as official violence against citizens (police brutality); violence that results from the nature of the state (patrichial nature) and violence resulting from the nature of political structure (politics of bitterness (Okome, 2014). Others have classified political violence as counter-insurgency, terrorism, rioting and civil war (Hewitt, 1993; Dumouchel, 2014), coup d'état (Theodore, 1998), revolution, rebellion, insurgency (Scharf, 1993, Harris, 1974; Cohan, 2002). Meanwhile, other scholars are not comfortable with the classification of terrorism as a political violence. They argued that terrorism should be excluded because of the subjective definition attached to it (Said, 1988; Jenkins, 1990). For some other scholars Like Young (1977), political violence is justifiable when it is interpreted in the concept of just war in which:

There is a failure to grant citizens effective means of peacefully gaining redress against tyrannical abuse of power; when these matters are not respected revolutionary activity will be justified if there is a strong likelihood the government (or sovereign) can be toppled without ensuing tyranny or anarchy and bloodshed of an inordinate extent.(cited in Cohan, 2006:917). 
Thus, we may tend to agree that terrorism is an aspect of political violence which is regarded as "a substitute for conventional war" (Hare, 1979 cited in Cohan, 2006:926). War is a state of organized, armed, and often prolonged conflict carried on between states, nations and other parties. It is often intensive and characterized by extreme aggression, social disruption and followed by high mortality which involves all genders (Merriam Webster Dictionary, 1998). War is simply a "military conflict between nations or parties" (Webster's Universal Dictionary and Thesaurus, 2010:513). War or otherwise known as armed violence is defined as "the intentional use (threatened or otherwise) against oneself, another person, or against a group or community of any material thing that is designed, used or usable as an instrument for inflicting bodily harm that either results in or has likelihood to result in injury, death, psychological harm, maldevelopment or deprivation" (http://www.utoronto.ca/ois/armed_violence/code.htm cited in Perouse de Montclos, 2011:7). It is certain that Nigerian state is at war with a fundamental religious sect known as Boko Haram.

Conflict is described as the resort to the use of force and armed struggle in the pursuit of incompatible and particular interest and goals by contending groups or individual (Oraegbunam, 2006). Thus, Shehu (2007) argues that conflict is inevitable in social life process and even in well developed human societies such as United States and Britain conflict occurs. Conflict may also be described as "a period of intense pursuit of incompatible goals by different groups" (Reychler, 2001:15). It must be stressed that in Nigeria, conflict of interest between groups be it in the political, economic, religious or social arena have most times ended violently resulting to great casualties. And in most cases, the effects on victims have remained permanently. Conflict refers to clash, contention, confrontation, a battle or struggle or quarrel between two or more individual, groups or nations (Nwolise, 1997).

Zartman (1991:300), argues that conflict is "the violent exhibition or expression of incompatibility, though conflict may become violent, however violence is not inherent aspect of conflict but rather a potential form which conflict may take. We agree that violence is not inherent aspect of conflict, but there has been no war (armed conflict) or political violence which has not ended in bloody conflict. Thus, Dahrendorf (1958) maintained that conflict is intrinsic to all societies and association due to perpetual competition for authority within such groups. Conflict is therefore inevitable in all human societies.

According to Stoller (1968) 'gender is a term that has psychological and cultural connotations; if the proper terms for sex are male and female, the corresponding terms for gender are masculine and feminine; these latter terms might be quite independent of biological sex' (Haralambos, 2007:93). Attah (2006) argues that gender is a social construction which is culturally determined. However, Idyorough (2005:2) contends that "gender issues are not women issues alone, they are issues of men and women and the attendant power relations between the sexes". Thus, political violence and war will negatively impact on the socio-psychological makeup of both genders.

\section{Theoretical Framework}

Extant literature has shown that conflict is inherent in every human society (Marx, 1977, Dahrendorf, 1959)) and that peace can exist separately of conflict, violence and war. However, war (armed conflict) is the only one aspect of violence which is "physical, open and direct (Galtung, 1969). Galtung (1969) went further to argue that a society cannot be described as peaceful where structural poverty, exclusion, intimidation, oppression, want, inequality, unemployment, fear and all sundry types of psycho-social pressures still constitute the society's mainstay. In sociological perspective, peace can be viewed as a condition of social harmony in which there are no social antagonisms; in which case individuals and groups are able to meet their social needs and expectation such as food, cloth, housing and social amenities for a worthy life (Haralambos and Holborn, 2008). The implication is that where these are lacking, there is contention between those who have and those who have not for the available resources in the society. Two basic theories - structural functionalism and dialectical materialism could be derived from the above. The paper will be discussed on these theories.

Scholars of structural functionalist looked at conflict as a function of the structural constituents of the society. Thus, poverty, unemployment, crime, social inequality, marginalization, relative deprivation, corruption, injustice, oppression and exploitation are regarded as sources of conflict which could lead to political violence and war. The general thought therefore, is that conflict exists in the society as a result of struggle for scarce resources (Ake, 1981, Coser, 1956; Chinwuizu, 1975; Lenin, 1972; Engels, 1970; Marx, 1977). Thus, peace is achieved where existing social structures perform their functions adequately, and supported by the requisite culture, social norms, and values (Haralambos \& Holborn, 2008; Goffman, 2004). On the other hand, the dialectical materialism which is propounded by Karl Marx (18181883) argues that peace can only be achieved on the basis that there are classless people in the society (Haralambos \& Holborn, 2008). The implication is that there should be a redistribution of resources which are heavily domiciled in the hands of few men in the society. It calls for a rethink in our political and economic structure to address the imbalance in the society. The consequence is that, political violence and war will continue to exist in society so long as unequal 
relations exist within societies. The dialectical contradictions which exist in the distribution of economic resources must be reviewed in order for societies to live in peace and harmony.

\section{Effects of Political Violence and War on Gender}

Political violence and armed conflict (war) has a variety of devastating effect on genders ranging from physical, social and psychological. The following are some of major consequences of political violence and war (armed conflict) on genders.

\subsection{Loss of life}

Political violence and war are parts and parcel of broader plague of violence that have ravaged the lives of tens of thousands of Nigerians since the country's return to civilian rule in 1999. We have to note that Nigeria recorded over 200,000 cases of death in the last two decades occasioned by political and religious precipitated wars or violence (AlbinLackey, 2007: Olasebikan, 2011; Soriwei, 2012; Obe, 2012; Chinwokwu, 2012c). More so, the Human Rights Watch (2013) reported that more than 1,000 lives were lost in North Central Nigeria between December 2013 and March, 2014 as a result of political and tribal wars in the Zone. This is aside the cases of death recorded since April, 2014 in the North East, Nigeria occasioned by religious war being carried out by Boko Haram. As a result many children became orphans during periods of political violence and war while men and women end up as widows and widowers. The pain of losing either children or parents affects individuals concerned socially and emotionally especially children because they are deprived of parental care, protection and love. We must emphasis that armed conflict (war) is a major threat to the aged and children lives, because they are considered as the most vulnerable when wars break out in any society.

\subsection{Displacement of People}

One of the social effects political violence and war have on gender is the displacement of people from their historical native homes and lands. In fact, between October 2010 and October 2011, the National Emergency Management Agency in Nigeria declared a total of 377,701 internally displaced persons (IDPs) as a result of violent conflicts with ethnic, religious and political undertones (Laden, 2012). According to Laden (2012), further statistical data on the volume and spread of IDS across the geographical landscape of Nigeria reveals the existence of about 1.4 million displaced persons as a result of conflict violence. Laden further stated that the North-East in terms of geographical zone or location has remained the home of the poorest zone in Nigeria since 1985, with the highest incidence of poverty (ranging below 54.9\% to $72.0 \%$ ). We should be reminded that this does not include the records of holocaust being caused by Boko Haram across Northern Nigeria. Social dislocation and displacement affect all gender groups of all ages, although, the weak and vulnerable members of the society - the aged, women and children suffer the most. In many instances women and young girls are subjected to sexual violence (rape) by even our very law enforcement officers that) are sent to protect them in areas of crisis. Families are sometimes disorganized especially the absence of real parents. Children are left without guardians or anyone to fend for them while young girls and women are forced into sexual trades.

\subsection{Separation from Family members}

In time of political violence and armed conflict (war), children of both sexes are separated from their parents. Children suffer most during crisis of any kind. Children are lost in the process of running away from attacks while others may be abandoned either because the aged parents or the children are regarded as weak to carry on with life. This was what happened during the 1967-1970 civil wars in Nigeria and in the reprisal attacks which followed after the killing of Ibos in Northern States of Nigeria in 1990. It is obvious that children were missing during time of war never get reunited with their parents. The implication is that such children end up being adopted if found alive while others end up growing up as slaves in the hands of their masters.

\subsection{Physical injury and starvation}

War affects both children and adults of both genders. Adults and children suffer starvation, hunger, malnutrition and diseases. Although, children suffer more from malnutrition, hunger, starvation and diseases than the adults. It is on record that Igbo children were victims of malnutrition, kwashiorkor, diarrhea and many diseases during the civil war. In some cases, children suffer permanent injuries - lost their limbs or legs while others died due to lack of medical care. A visit to 
the camps where displaced persons are kept in Benue and Nasarawa states as a result of the Fulani - Tiv attacks will speak volumes of the kind of conditions that people passes during periods of arm conflict and political violence.

\subsection{Abduction and Sexual Abuse}

During political violence and war, boys and girls suffer varying degrees of sexual abuses. According to Craddle (2007), during armed conflict, it is a common practice to have girls and boys recruited for sexual purposes ranging from force marriage, child sex slaves, child girl early marriage and rape. Nigeria is currently battling to rescue over 200 teenage school girls and 64 women abducted by Boko Haram from Chibok in Borno state of North East, Nigeria. The tale of those girls who have escaped from Boko Haram den is quite unsavory. It is an experience no sane parents would like their daughters to pass through in life no matter what. We note that paragraph 135 of Beijing Platform of Action of the Fourth World Conference on Women in 1995 condemns sexual slavery, rape, sexual abuse and forced pregnancy (Population Reference Bureau, 1996), however political violence and war (armed conflicts) have taken great toll on these and government are a crisis situation at checkmating the trend. The psychological effects can be devastating and life-long unless it is timely and appropriately addressed.

\subsection{Disruption of Social Services}

One of the social effects of political violence and war is the disruption of social services like education, hospitals and trade. Today, school buildings have been destroyed and schools have been closed down in Borno, Adamawa and Yobe states, Nigeria due to insecurity occasioned by the activities of Boko Haram insurgency. The implication is that genders of all age descriptions especially the youths have been denied of basic education and their fundamental rights completely infringed. The long term effect is that the future of these children in the affected states is bleak. It will take decades for the states to recover from this waste of human capital. Furthermore, war brings about shortage in food, production, distribution and supply as homelands and farms are abandoned, consequently leading to great hunger and starvation. For example, it is observed that during the Fulani herdsmen and Tiv war in Benue and Nasarawa states, the Tivs abandoned their homes and farms leading to scarcity of food in the states. A visit to Adamawa, Borno and Yobe states will also indicate the disruption in trade activities as Igbo traders have left the area to more peaceful states.

\subsection{Emotional and Psychological Sufferings}

Political violence and war affect the genders, although children suffer the most. Young boys and girls who suffer sexual abuses are left completely traumatized. Aside from the physical health problems - injury, chronic pain syndrome, HIVIAIDS, permanent disability and range of mental health issues, the psychological effects of sexual abuse are considered more serious and dangerous than its physical effects. The experience is rather demeaning and humiliating and affects the girl's self esteem and put them at greater risks of mental problems like depression, post traumatic stress disorder, phobia and suicide, alcohol and drug abuse. Further emotional and psychological effects will include: mistrust, shame, and guilt, fear of sexual activities, revenge and withdrawal from society. Aside from these, one of the effects of political violence and war is the generation of fear. Fear generated by war or rumours of war produce great tension, anxiety, insecurity which can easily be manipulated by the political class to their advantage. The case of Boko Haram bombing extending to the South and East, Nigeria and the psychological stress and trauma had generated in the minds of the citizenry across the country is better imagined. Thus "the fear of Boko Haram is the beginning of safety" is the slogan making waves in the country.

\section{Conclusion and Recommendations}

War and political violence portend great danger to the development of the nation. There is no nation that thrives well under the heat of war (armed conflict) and political violence. We can only progress and have meaningful development under the atmosphere of tranquility, peace and harmony. Therefore, government must endeavour to avoid anything that will cause disharmony and disequilibrium in the polity. Nigerian politicians must eschew politics of bitterness, rancor, criminality and falsehood. Every individual must be given equal opportunity and level playing ground to participate in the politics without any acrimony. Demands for change in the polity should be done maturely and democratically rather than undemocratic and clandestine methods. Democratic principles and due processes should be applied at all levels of governance in electing political leaders rather than selective principle and imposition of political candidates on the 
electorate. The principle of equity, fairness, and justice should be our political slogan in the coming 2015 election. The adherence of these norms in our polity will go a long way in reducing areas of discontent and help in building bridges across the nation for peaceful co-existence and unity.

Government must create developmental programmes towards the elimination of poverty and empowerment of the youth. There is frustration, misery, stress, economic imbalance and inequitable distribution of wealth which has given rise to unemployment in the country. The result is that only a handful of the people are rich while majority are languishing in abject poverty.

Government must address urgently the rising profile of Boko Haram insurgency and general insecurity in the country. The masses of this country especially school children, women and physically challenged in the society must be assured of their safety. Students in Nigerian colleges must be secured and protected. The fundamental human rights of the child especially the girl child must be protected by all government agencies. Police brutality and government use of force to quell riots must be reviewed especially in a democratic setting.

Government a matter of urgency should as liaise with foreign partners and stakeholders in the country to ensure that Chibok school girls and other Boko Haram women abducted by are rescued to wipe out the national shame this news has brought to the nation. Our security agencies should be adequately equipped to be able to execute their constitutional duties without constraint. We must not leave the security of the country in the hands of foreigners, our sovereignty as a country must be maintained.

There should be a synergy of all security agencies in the country to ensure that intelligence are shared for prompt action in order to curb conflict at its bud. In this line, the society needs some kind of security awareness to enable them police their environment and report properly issues of security threat to appropriate agencies.

There should be an integrative approach in handling issues of conflicts in Nigeria for the survival of our nascent democracy. Government must continue to engage in dialogue with all key stakeholders in involved in any conflict situation to ensure contending issues are resolved peacefully. Consequently, women themselves should be involved in conflict resolution and be trained to be security conscious and above all encourage relying on their creator as this will lead to emotional stability.

There is no alternative to peace, except war and destruction. Government must endeavour to engage in meaningful developments to avoid issues of mistrust, marginalization, poverty, unemployment, corruption, inequality etc. in the country.

\section{References}

Ake, C. (1981). A political economy of Africa. London: Longman.

Albin-Lackey, C (2007). Criminal politics.violence, godfathers and Corruption in Nigeria. New York: Human Rights Watch

Amnesty International, (2004).Making violence against women count: Facts and figures. Amnesty International: New York, U.S.A.

Chinwokwu, E. C. (2012c). History and dynamics of terrorism in Nigeria: Socio-Politica dimension. International Journal of Innovative Research and Development. 1(11):419-446. Retrieved from http://www.ijird.com/

Chinwuizu. (1975). The west and the rest of us white predators, black slaves and the African elite. New York: Random House.

Coser, L. (1956). The functions of social conflict. New York: Free Press

Cohan, J. A. (2006). Necessity, political violence and terrorism. Retrived from http://www.usafraic.com/necessity-political-violence-andterrorism/pdf

Cohan, J. A. (2002). Formulation of state's responses to terrorism and state sponsored terrorism. Pace International Literature Review, 14 (48):77-87.

Craddle. (2007). Children in armed conflict: An information pack. Nairobi: Craddle

Dahrendorf, R. (1958). Out of Utopia: Towards a reorientation of sociological analysis. American Journal of Sociology, 2: 133-147

Dahrendorf, R. (1959). Class and class conflict in an industrial society. London: Routledge \& Kegan Paul

Engels, F. (1970). The origins of the family, private property and the state. New York: International Publishers.

European Union Election Observation Mission, (2007).Statement of preliminary findings and conclusions, April 23, 2007.Retrieved from http://www.eueom-ng.org.

Hansford, K., Bendor-Samuel, J., \& Stanford, R. (1976).Studies in Nigerian languages, No. 5: An index of Nigerian languages. Accra: Summer Institute.

Haralambos, M., \& Holborn, M. (2008). Sociology: Themes and perspectives (7thed.). London: HarperCollins Publishers Limited.

Harris, J. (1974). The Marxist conception of violence.Philosophy and Public Affairs, 3, 192-201

Human Rights Watch. (2007). Election or selection?: Human rights abuse and threats to free and fair elections in Nigeria, April 2007, retrieved from http://hrw.org/backgrounder/africa/nigeria0407.

Human Rights Watch. (2011). Nigeria: Post election violence killed 800. May 16.

Human Rights Watch. (2014, April 15). Nigeria: 1000 killed in Central Nigeria. Premium Times. p. 3

Hewitt, C. (1993). Consequence of political violence. Aldershot: Dart Mouth Publishing Company Limited. 
Galtung, J. (1969). Violence, peace and peace research.Journal of Peace Research. 6

Idyorough, A. E. (2005). Gender: Concepts and issues in Nigeria. Markudi: Aboki Publishers.

Jenkins, B. (1990). International terrorism: The other world. In Charles Kegley (Ed.), International Terrorism: Characteristics, causes, controls (pp.27-38). New York: St. Martins Press.

Laden, M. T. (2012).Impact of insecurity in the North on internally displaced people and migration flows between Nigeria and neighbouring countries. Being a paper presentation made at the Forum of European Union working group on migration and development organized by the Delegation of European Union to Nigeria at EU Meeting Room 1, Portakabin 21st Crescent off Constitution Avenue CBD, Abuja on May 31, 2012. Retrieved from http://docs.google.com/impact+of+terrorism.html/

Lenin, V. I. (1972). Collected works, Moscow: Progress Publishers.

Marx. K (1977).Communism and the Augusburger Allegemeine Zeitung.In D. McLellan (Ed.). Karl Marx: Selected writings. (pp. 20-21), New York: Oxford University Press.

Mazefsky, C. A \&, Farrel, A. D. (2005). The role of witnessing violence, peer provocation, family support, and parenting practices in the aggressive behavior of rural adolescent. Journal of Child and Family Studies, 14 (70):71-85

Nwolise, O.B.C. (1997). ECOMOG peace-keeping operation in Liberia: Effect on political stability in the West African Sub-Region. African Review, Journal of National Defense College, 1(1): 36-60

Obasanjo, O. (2002). Political thurgery and violence in Nigeria: The bane of women participation in politics. Retrieved from http://www.articlebase.com/politics-articles/political-thurgery-and- violence-in-nigeria-the-bane-

Obe, E. (2012, January 12).Boko Haram leaders defends attacks. The Punch, p.8

Okolie, A. M. (2008). Child soldering and African security in the post cold war international relations: Lessons from Democratic Republic of Congo. Journal of Liberal Studies. 12(1-2), 51-63

Okome, M. O. (2014). Gender and political violence in Nigeria.Retrieved from http://www.mojubaolu.blogspot/2007/12/gender-andpolitical-violence-in-nigeria/html.

Olaosebikan, D. (2011, June 3). Jonathan and unfolding Afghanistaization of Nigeria. National Mirror, p. 17.

Omoweh, D. \&, Okanya, D. (2005).Community unrest and threat to Nigeria's national security. In Ogwu, U. J (Ed.), New horizon for Nigeria in world affairs (pp.293-311), Lagos: NIIA

Oraegbunam, K. E. (2006). The metaphysical foundation of contemporary armed conflict: Implications for human dignity and global peace. In Odimegwu et al. (Eds.).Philosophy, Democracy and conflicts in Africa, (pp. 218-232), Akwa: Department of Philosophy.

Paden, J (2008) Faith and politics in Nigeria: Nigeria as a pivotal state in the Muslim World. Washington, D.C: United States Institute for Peace (USIP)

Perouse de Montclos, M. (2011). Nigeria watch: Third report on violence in Nigeria 2006-2011. Abuja: Nigeria Watch.

Population Reference Bureau.(1996). The World youth, Washington psychology today.Retrieved from http://psychologytoday.com/conditions/pedophilia.html/

Quota, S., Punamaki, R. L., \&, El- Sarraj, E. (2008). Child development and family mental health in war and military violence: The Palestinian Experience. International Journal of Behavioural Development. 32 (4):310-321

Reychler, L. (2001a), Conceptual framework. In L. Reychler \& T. Paffenholz (Eds.).Peace building: A Field guide. London: Lynne Rienner

Sagi-Schwartz, A., Seginer, R., \&, Abdeen, Z. (2008). Chronic exposure to catastrophic war experiences and political violence: Links to well-being of children and families. International Journal of behavioural Development 32 (4): 257-269.

Said, E. (1988). American intellectuals and Middle East politics: An interview with Edward W. Said. Interviewer Bruce Robbins.Social Text 1(20), 37-53

Salawu, B. (2010) Ethno-Religious conflict in Nigeria: Causal analysis and proposals for new management strategies. European Journal of Social Sciences. 13(3) 345-353

Scharf, A. (1973). Marxist theory on revolution and violence. Journal of History of Ideas, 34, 263-271

Segun, J. (2013). Democracy and violent conflicts in Nigeria: Implications for national development. African Research Review, an International Multidisciplinary Journal, Ethiopia 7(3), 324-339.

Shehu, S. (2007). The killing fields: Religious violence in Northern Nigeria. Ibadan: Spectrum Books

Soriwei, F. (2012, January 18). Boko Haram plans to take over North-FG. The Punch, p. 8.

Stavrou, V. (1993).Psychological effects of criminal and political violence on children. The Child Worker 11(7):3-9

Theodore, M. (1998).Crimes and accountability in Shakespeare.American Journal of Literature, 1(5). $\quad 92-95$

Tiffen, B. W. (1968). Language education in commonwealth Africa. In J. Dakin et al (Eds.), Language in education. London: Oxford University Press.

United Nations (2000b). The state of world population 2000.United nations General Assembly, Fifty-fifth Session. United Nations Population Fund, United Nations.

Young, R. (1977). Revolutionary terrorism, crime and morality. Sociological Theory and Practice4: 287- 297.

Zartman, I. W. (1991). Conflict reduction, prevention management and resolution.In Deng, F. M \& W. I. Zartman (Eds.).Ethnic violence threatens Nigeria's democracy. New York: Sage 